\title{
VICTIM IMPACT STATEMENTS AND SENTENCING HOMICIDE OFFENDERS: A CRITICAL ANALYSIS OF RECENT CHANGES TO THE CRIMES (SENTENCING PROCEDURE) ACT 1999 (NSW)
}

\author{
TRACEY BOOTH*
}

The use of victim impact statements ('VISs') from family victims in homicide matters, particularly as evidence of aggravating factors, is contentious in NSW courts. Until July 2014, the law prevented VISs influencing penalties imposed on homicide offenders (Previtera). However, the Crimes (Sentencing Procedure) Act 1999 was amended in 2014 in order to overrule Previtera and enable VISs to 'count' in sentencing homicide offenders. This article draws on a case study of 39 homicide sentencing judgments, July 2014-April 2017, to determine whether, and if so the extent to which, the new law has changed the role of VISs from family victims in sentencing. It also considers the practical implications of these findings for future family victims and argues that not only has the new law made little practical difference to the use of VISs in homicide matters, but there are also potential adverse consequences for family victims in the sentencing process.

\section{INTRODUCTION}

Legislation has facilitated the submission of victim impact statements ('VISs') by crime victims to New South Wales ('NSW') sentencing courts for the past two decades. ${ }^{1}$ VISs are complex and highly nuanced narratives that recount the harm victims have suffered as a result of the crime, and serve multiple instrumental and expressive functions in the sentencing hearing. ${ }^{2}$ From an instrumental perspective, it is said that sentencing judges can use VISs to serve sentencing objectives such as deterrence, retribution and offender

\footnotetext{
* Associate Professor, Faculty of Law, University of Technology Sydney. The author would like to thank the anonymous reviewers and Dr Tyrone Kirchengast for their constructive feedback and suggestions.

1 Originally located in the Criminal Procedure Act 1986 (NSW) s 23C and now located in the Crimes (Sentencing Procedure) Act 1999 (NSW) ss 26-30A.

2 Tracey Booth, Accommodating Justice: Victim Impact Statements in the Sentencing Process (Federation Press, 2016); Julian V Roberts and Edna Erez, 'Communication in Sentencing: Exploring the Expressive Function of Victim Impact Statements’ (2004) 10 International Review of Victimology 223.
} 
desistance. ${ }^{3}$ The information provided in VISs can assist judges to properly assess the seriousness of the offending and enhance the proportionality of the penalty imposed. ${ }^{4}$ On the other hand, the expressive functions of a VIS are victim-focused. Erez argues that VISs were originally conceived to redress the exclusion and marginalisation of victims in adversarial sentencing hearings as well as improve their courtroom experiences. ${ }^{5}$ From this perspective, VISs can provide victims with a defined role in the sentencing process, a 'voice' to communicate their experiences of victimisation to the court, the offender and the wider community, and opportunities to be recognised and acknowledged. ${ }^{6}$

Although VISs are a well-entrenched feature of the sentencing landscape in NSW (at least in superior courts), the role of VISs submitted by members of the deceased's family ('family victims') in homicide cases has been contentious from the outset. ${ }^{7}$ Prior to 1 July 2014, the relevant legislation required the sentencing court to accept and acknowledge a VIS from a family victim. However, the court was not required to take that statement into account in the determination of the penalty unless it 'considered it appropriate to do so' ${ }^{8}$ Subsequently, a line of authority developed whereby it was regarded as inappropriate for a sentencing court to use a VIS from a family victim to influence penalty when the contents of that statement were limited to the impact of the deceased's death on family members. ${ }^{9}$ This principle was said to be largely underpinned by a fundamental tenet of criminal justice - equality before the law - and articulated by Hunt CJ at $\mathrm{CL}$ in the seminal case of Previtera: 'it would ... be wholly inappropriate to

3 Booth, Accommodating Justice, above n 2, 34-6; Lynne Henderson, 'The Wrongs of Victims Rights' (1985) 37 Stanford Law Review 937, 986-1006; Andrew Ashworth, 'Victim Impact Statements and Sentencing' [1993] Criminal Law Review 498; Sam Garkawe, 'The Role of the Victim during Criminal Proceedings' (1994) 17 University of New South Wales Law Journal 595; Andrew Sanders et al, 'Victim Impact Statements: Don't Work, Can't Work' [2001] Criminal Law Review 447; Julian Roberts and Marie Manikis, 'Victim Personal Statements: A Review of Empirical Research' (Report to Commissioner for Victims and Witnesses in England and Wales, October 2011).

4 Roberts and Manikis, 'Victim Personal Statements', above n 3; Tyrone Kirchengast, 'Proportionality in Sentencing and the Restorative Justice Paradigm: "Just Deserts" for Victims and Defendants Alike?' (2010) 4 Criminal Law and Philosophy 197; Rita Shackel, 'Victim Impact Statements in Child Sexual Assault Cases: A Restorative Role or Restrained Rhetoric?' (2011) 34 University of New South Wales Law Journal 211.

5 Edna Erez, 'Victim Voice, Impact Statements and Sentencing: Integrating Restorative Justice and Therapeutic Jurisprudence Principles in Adversarial Proceedings' (2004) 40 Criminal Law Bulletin 483, 484.

6 Roberts and Erez, above n 2; Sam Garkawe, 'Victim Impact Statements and Sentencing' (2007) 33 Monash University Law Review 90.

7 For the purposes of this article 'homicide' covers the following offences: murder, manslaughter and driving offences causing death. Under s 26 of the Crimes (Sentencing Procedure) Act 1999 (NSW) a family victim is a member of the primary victim's immediate family, which means: the victim's spouse; the victim's de-facto partner; the person to whom the victim was engaged to be married; a parent, grandparent, guardian or step-parent of the victim; a child, grandchild or step-child of the victim or some other child for whom the victim was the guardian; and a brother, sister, half-brother, half-sister, stepbrother or step-sister of the victim.

8 As originally enacted, s 23C of Criminal Procedure Act 1986 (NSW); later incorporated in s 28(4) of Crimes (Sentencing Procedure) Act 1999 (NSW).

$9 \quad R v$ Previtera (1997) 94 A Crim R 76 ('Previtera'); $R v$ Bollen (1998) 99 A Crim R 510 ('Bollen'); $R v$ Dang [1999] NSWCCA 42; SBF v The Queen (2009) 198 A Crim R 219. 
impose a harsher sentence upon an offender because the value of the life lost is perceived to be greater in the one case than it is in the other'. ${ }^{10}$

In 2014, the Crimes (Sentencing Procedure) Act 1999 (NSW) ('CSPA') was amended in order to overrule Previtera and change the approach of the NSW sentencing courts to the role of VISs in the sentencing of homicide offenders (the 'new law'). This new law is part of several sentencing laws implemented by the NSW government in the wake of the much publicised manslaughter of Thomas Kelly by Kieran Loveridge in 2012 and the perceived lenience of the penalty imposed on Loveridge in 2013 by the sentencing court. ${ }^{11}$ According to the then Attorney-General, this case brought the issue in Previtera 'to a head' and 'the fact that family victim impact statements appeared not to count for anything was roundly condemned in some quarters' ${ }^{12}$ Under the new law, in appropriate cases sentencing courts are enabled to take account of VISs from family victims in formulating penalty as an aspect of harm done to the community. The second reading speech for the Crimes (Sentencing Procedure) Amendment (Family Member Victim Impact Statement) Bill 2014 (NSW) makes it clear that by the new law, the government intends for VISs from family victims to 'count for something' by having an enhanced role in the sentencing of homicide offenders. ${ }^{13}$

This article explores whether and, if so, the extent to which the new law has changed the role of VISs from family victims in sentencing homicide offenders in NSW. It also considers the implications of the practical operation of the new law for future family victims. It is argued that not only has the new law made little practical difference to the way in which VISs are used by sentencing courts in homicide matters, but also that the operation of the new law has the potential for adverse consequences for family victims in the sentencing process.

\section{THE ROLE OF VISS IN SENTENCING HOMICIDE OFFENDERS BEFORE 1 JULY 2014}

\section{A Instrumental Function}

Following a decade of discussion and debate, ${ }^{14}$ the Criminal Procedure Act 1986 (NSW) was amended in 1997 to enable both primary and family victims to submit VISs to the sentencing court. Section 23C(3) provided that the court must receive and acknowledge receipt of VISs from family victims but it 'must not consider' those statements 'in connection with the determination of the

10 Previtera (1997) 94 A Crim R 76, 86-7.

11 The sentencing and re-sentencing of Loveridge will be discussed in detail below. For a discussion of other related sentencing laws see Julia Quilter, 'One-Punch Laws, Mandatory Minimums and "AlcoholFuelled” as an Aggravating Factor: Implications for NSW Criminal Law' (2014) 3(1) International Journal for Crime, Justice and Social Democracy 81.

12 New South Wales, Parliamentary Debates, Legislative Assembly, 7 May 2014, 28361 (Brad Hazzard, Attorney-General).

13 Ibid 28 360-2 (Brad Hazzard, Attorney-General).

14 New South Wales Law Reform Commission, Sentencing, Report No 79 (1996) 34 [2.22]. 
punishment for the offence unless the court considers that it is appropriate to do so'.

Shortly after it commenced, the effect of section $23 \mathrm{C}(3)$ was considered in Previtera. There, Hunt CJ at CL accepted a VIS from the deceased's son but ruled that it was not appropriate to take it into account in the determination of penalty because it was limited to the impact of the deceased's death on her family. His Honour approached the sentencing task on the basis that the objective circumstances of the offence encompassed the death of the deceased and the manner and circumstances in which she had died. Information regarding the impact of the deceased's death on family members had no bearing on the death or the manner and circumstances of that death and was, therefore, not relevant to an assessment of the objective circumstances of the offending. In such circumstances, the VIS served no instrumental purpose in the assessment of the seriousness of the offence. Hunt CJ at CL was also concerned that taking account of VISs in such cases might lead to the imposition of a penalty reflecting the value and worthiness of the deceased person rather than the culpability of the offender.

It is regarded by all thinking persons as offensive to fundamental concepts of equality and justice for criminal courts to value one life as greater than another. It would therefore be wholly inappropriate to impose a harsher sentence upon an offender because the value of the life lost is perceived to be greater in the one case than it is in the other. ${ }^{15}$

Previtera was subsequently endorsed by the NSW Court of Criminal Appeal ('CCA'). ${ }^{16}$ While the VIS provisions were reformatted and incorporated into section 28 of the CPSA in 1999, the essential wording of the provision remained the same.

Section $3 \mathrm{~A}(\mathrm{~g})$ was inserted into the CSPA in 2002 and it stipulates that a purpose of sentencing is to 'recognise the harm done to the victim of the crime and the community'. ${ }^{17}$ Spigelman CJ indicated in $R v$ Berg that it might be time to revisit Previtera and consider whether this provision introduced a new element to the sentencing task.

The reasons given in Previtera may need to be reconsidered in an appropriate case ... It appears to me strongly arguable that the recognition of this purpose of sentencing [ie harm to the community] would encompass the kind of matters which are incorporated in a victim impact statement. It may in some cases, be appropriate to consider the contents of such statements in the sentencing exercise. This is not a purpose of sentencing recognised by Hunt CJ at CL in Previtera ... ${ }^{18}$

Implicit in these remarks is a conception of harm, relevant to the assessment of the objective seriousness of homicide offences, that is broader than that

15 Previtera (1997) 94 A Crim R 76, 86-7.

16 Bollen (1998) 99 A Crim R 510, 529 (Hunt CJ at CL); $R v$ Dang [1999] NSWCCA 42, [15] (Abadee J); $R v$ Wickham [2004] NSWCCA 193, [25] (Howie J); $R v F D$ (2006) 160 A Crim R 392, 415-16 (Sully J), 428-9 (Hulme J); MAH v The Queen [2006] NSWCCA 226; SBF v The Queen (2009) 198 A Crim R 219, 237 [86] (Johnson J).

17 Crimes (Sentencing Procedure) Amendment (Standard Minimum Sentencing) Act 2002 (NSW) sch 1 item 1.

18 [2004] NSWCCA 300, [43]-[44]. Although $R v$ Berg involved a driving offence causing death, it was not an appropriate case to decide this issue because no VIS had been submitted by a family victim. 
propounded by Hunt CJ at CL in Previtera (death and manner of death). It is a conception of harm that extends to the consequences of offending for family victims and the community. Though this issue was not specifically addressed or resolved in later cases, two subsequent CCA decisions suggest that nonetheless a shift did take place in sentencing homicide offenders whereby the broader conception of harm posited by Spigelman CJ was indeed being applied in the evaluation of the objective circumstances in homicide cases.

The first case, $M A H v$ The Queen, was an appeal against sentence where the Crown argued that the sentencing judge had erroneously used Previtera to support a ruling that the VIS was irrelevant. ${ }^{19}$ As a result of this error the judge did not take into account relevant circumstances including:

the increased culpability of murdering a friend of whose family circumstances and likely effect upon whom he would have been aware, and, an increase of harm to a substantial degree by a breach of trust and an exacerbation of the harm done by the conduct of the respondent. ${ }^{20}$

This ground of appeal was dismissed. Grove J, with whom the other members of the Court agreed, found that although the sentencing judge said that the rule in Previtera meant that the VIS was not relevant to penalty, this comment 'should be understood in the context of [the later remarks]' made by the sentencing judge to the effect that the impact of the death of the victim on the family was not a factor that could aggravate the offence. ${ }^{21}$ The consequences referred to by the Crown were part of the objective circumstances of the offence that the sentencing judge described and took into account in sentencing: rather than ignoring the VIS from the deceased's mother, the judge in fact properly discussed its contents. ${ }^{22}$

In the second case, $S B F$ v The Queen, the appellant argued that the sentencing judge had taken account of the VISs submitted in a manner contrary to law because the judge had referred to the VISs extensively in the judgment without reference to Previtera. ${ }^{23}$ During sentencing the judge had discussed the content of the VISs and said: 'I have taken these statements into account in the way that it is appropriate to do so on sentence'. ${ }^{24}$ In relation to the defence submissions regarding the VISs (where Previtera had been referred to in argument) the judge said:

[defence counsel] submitted that whilst the victim impact statements excited feelings of sadness they were not relevant to sentencing proceedings. Whilst this may be strictly true, in my view they do no more than outline, in a very real way, a glimpse of what must be expected to flow from the deaths of two young men and the very serious injury of a young woman. ${ }^{25}$

On appeal, the Crown argued that it was clear the sentencing judge was conscious of the limitations on the use of VISs imposed by Previtera and did not

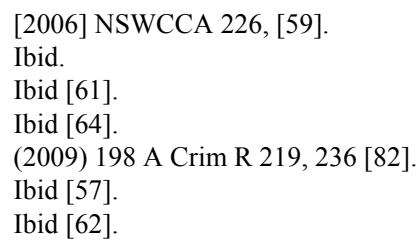


make an error with regard to the use of VISs. ${ }^{26}$ It was also submitted that Previtera does 'not preclude the general relevance of the acknowledged fact that death is attended by distress and his Honour's comments did no more than demonstrate that point by reference to the victim impact statements' ${ }^{27}$ The CCA agreed with these submissions and found no evidence that the 'experienced' judge had taken account of the VISs contrary to the principle in Previtera. ${ }^{28}$ The Court also referred to section $3 \mathrm{~A}(\mathrm{~g})$ and noted that a purpose of sentencing is 'to recognise the harm done to the victim of the crime and the community' ${ }^{29}$ In this context, the CCA found that there are no restrictions on the extent to which a sentencing judge can discuss VISs in a judgment and indeed, in this case:

It is understandable ... that his Honour set out the contents in some detail ... The victim impact statements outlined the devastating consequences upon the families of the deceased young men and also the profound effects upon the young woman who survived the collision. ${ }^{30}$

The approach of the CCA indicates that at the time the new law commenced the principle in Previtera was confined to prohibiting the use of VISs as evidence of aggravating factors in sentencing homicide offenders. Application of this principle did not mean that the harm caused to family victims was irrelevant and ignored by sentencing courts. The harm caused to family victims - that the dying and death of the deceased 'is attended by distress' - was clearly recognised as part of the objective circumstances of the offence and intrinsic to the nature and seriousness of homicide offending. From an instrumental and expressive perspective, acknowledgment and comment on VISs in sentencing judgments served to both recognise the impact of the offending on the family victims and exemplify why homicide offences are regarded as the most serious of offences. This position was also consistent with the approach taken to VISs in other Australian jurisdictions. For example, in $R v$ Beckett Vincent $\mathrm{J}$ said:

The introduction of such statements was not ... intended to effect any change in the sentencing principles which govern the exercise of discretion by a sentencing judge. What such statements do is introduce in a more specific way factors which a court would ordinarily have considered in a broader context. They constitute a reminder of what might be described as the human impact of the crime. ${ }^{31}$

\section{B Expressive Function}

VISs served a major expressive role in the sentencing process under the former law. Family victims were able to speak and be heard about the impact of the deceased's death, and their experiences of victimisation were recognised and acknowledged by the court, particularly in those matters where victims elected to read their VIS aloud to the court. ${ }^{32}$ Research shows that expressive functions of VISs are particularly important for a large proportion of victims who choose to

26 Ibid [84].

27 Ibid.

28 Ibid [90]-[91].

29 Ibid [89] (emphasis in original).

30 Ibid [88].

31 [1998] VSC 219, [79].

32 Family victims have been able to read their VIS aloud to the court since 2003: see CSPA s 30A. 
participate in the sentencing process. ${ }^{33}$ Indeed, there was consensus among family victims interviewed for a qualitative study of family victim participation in homicide sentencing in NSW ('the NSW study') that their VIS was a highly valued opportunity to be heard. ${ }^{34}$ Study participants appreciated the opportunity to talk about their experiences of victimisation and express their feelings about the crime to the court, the offender and the wider community. ${ }^{35}$ Also important was the opportunity for their VIS to be a device through which to make the deceased visible in the court proceedings. One family victim in this study said she was 'highly motivated' to submit a VIS because:

I was very mindful that there was only one real aim of my VIS - to give a picture of [the deceased] how much he was loved and how much he was missed. The legal system is all about the other person, it's all about the murderer, there's nothing about the victim ... so as far as I'm concerned [the deceased] was lost in the system ... I just wanted to be a voice for [the deceased]. ${ }^{36}$

Another significant finding of the NSW study was use of sentencing judgments to convey recognition and acknowledgement of family victims' loss and suffering through their comments made in relation to the VISs. ${ }^{37}$ Consistent with research, validation in this manner was particularly important for victims in the study and greatly appreciated. ${ }^{38}$ Not only did judges remark upon the nature and extent of family victims' loss but also in some cases, commended victims variously for their courage, empathy and recovery. ${ }^{39}$

In conclusion, it is evident that at the time the legislation was amended in 2014, VISs did 'count for something' through both an instrumental and expressive role in the sentencing of homicide offenders. The next section turns to analyse the new law.

\section{THE NEW LAW}

This section commences with an analysis of $R v$ Loveridge, ${ }^{40}$ the catalyst for the change in the law.

33 Edna Erez, Peter R Ibarra and Daniel M Downs, 'Victim Welfare and Participation Reforms in the United States: A Therapeutic Jurisprudence Perspective' in Edna Erez, Michael Kilchling and Jo-Anne Wemmers (eds), Therapeutic Jurisprudence and Victim Participation in Justice: International Perspectives (Carolina Academic Press, 2011) 15, 24-8; James Chalmers, Peter Duff and Fiona Leverick, 'Victim Impact Statements: Can Work, Do Work (For Those Who Bother to Make Them)' [2007] Criminal Law Review 360; Victoria Department of Justice, Victim Support Agency, 'A Victim's Voice: Victim Impact Statements in Victoria: Findings of an Evaluation Into the Effectiveness of Victim Impact Statements in Victoria' (Report, October 2009); Roberts and Manikis, 'Victim Personal Statements', above $\mathrm{n} 3$.

34 Booth, Accommodating Justice, above n 2, 64-5.

35 Ibid.

36 Quoted in ibid 65.

37 Tracey Booth, "'Cooling Out" Victims of Crime: Managing Victim Participation in the Sentencing Process in a Superior Sentencing Court' (2012) 45 Australian and New Zealand Journal of Criminology 214.

38 Roberts and Manikis, 'Victim Personal Statements', above n 3, 27.

39 Booth, Accommodating Justice, above n 2, 150.

$40 \quad R v$ Loveridge [2013] NSWSC 1638. 


\section{A $R$ v Loveridge}

Loveridge was 18 years old and heavily intoxicated when he committed five unprovoked assaults 'randomly on unsuspecting strangers' over a one-hour period in Kings Cross on 7 July 2012.41 One of these assaults was a single punch to Thomas Kelly's head that caused him to fall and sustain fatal injuries as a result of his head hitting the footpath. ${ }^{42}$ Loveridge pleaded guilty to three common assaults, one assault occasioning actual bodily harm, and manslaughter. ${ }^{43}$ At sentencing, Campbell $\mathrm{J}$ found that while the manslaughter offence fell into a 'category of some seriousness', ${ }^{44}$ there were matters that favoured a degree of leniency including: an early guilty plea; genuine remorse; good prospects for rehabilitation; and the youth of the offender. ${ }^{45}$ Loveridge was sentenced to imprisonment for six years with a four-year non-parole period for the manslaughter offence and overall he was sentenced to a total of seven years and two months imprisonment with a non-parole period of five years and two months. ${ }^{46}$

VISs submitted to the sentencing court by family victims were the subject of extensive comment in the judgment. Consistent with Previtera, Campbell J noted that the Court was not entitled to treat the 'grief and anguish suffered by the family ... as a circumstance aggravating the offence'. ${ }^{47}$ However, Campbell $\mathrm{J}$ also acknowledged the nature and extent of the loss and suffering of the deceased's family as well as the personal qualities of the deceased:

I have ... listened very carefully to the statements read by or on behalf of Thomas' immediate family, including his sister, maternal grandparents, and mother and father. From them I have formed the impression that Thomas must have been a wonderful young man full of promise for the future, and of whom his parents were justly proud. ... I am sure that every right thinking member of our community has a great of deal of sympathy for the Kelly family. I offer sincere condolences on behalf of the Court, and personally. ${ }^{48}$

In addition, the sentencing judge pointed out that the court could not take account of the attitude of the deceased's family in relation to the sentence to be imposed in the matter. ${ }^{49}$ It seems likely that this remark was in response to matters raised in the VISs and the judge's response reflects the common law position that the victim's attitude to the penalty is generally regarded as irrelevant. ${ }^{50}$ Ultimately, in this case, although the VISs were not used to aggravate the offending, it is clear that VISs were not ignored or regarded as irrelevant to the objective seriousness of the offence.

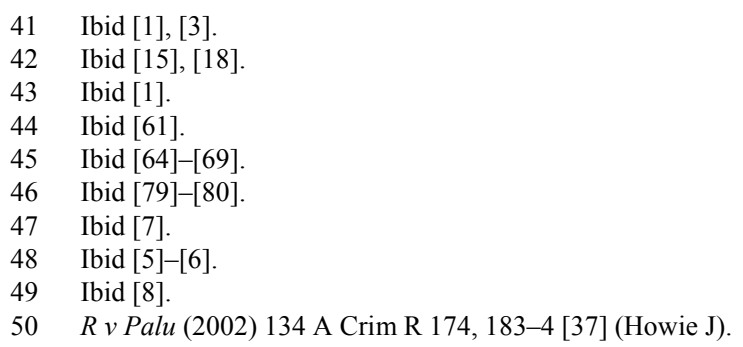


This case attracted extensive media attention and community disquiet, particularly in relation to the perceived leniency of the penalty imposed.$^{51}$ The subsequent Crown appeal against sentence was upheld; the original sentences were quashed and Loveridge was resentenced to a significantly higher penalty. For the manslaughter of Thomas Kelly, he was sentenced to 10 years and 6 months imprisonment with a non-parole period of 7 years, and the overall penalty was 13 years and 5 months with a non-parole period of 9 years and 9 months. ${ }^{52}$ The CCA described the manslaughter as 'grave' and found that the sentencing judge gave too much weight to the offender's subjective circumstances and insufficient weight to general and personal deterrence. ${ }^{33}$ General deterrence was a particularly significant consideration in this case because of the nature of the crime - unprovoked 'alcohol-fuelled' violence in a public space. ${ }^{54}$ The CCA also acknowledged the VISs, before the sentencing court, noting that '[t]hese statements reflect the profound grief experienced by members of Mr Kelly's family ... It is entirely apparent that the consequences of the loss ... in these tragic circumstances, will be not just long lasting but permanent'. ${ }^{5}$

\section{B Analysis of the New Law}

The new provisions of the CSPA became operative on 1 July 2014 and apply to the sentencing of homicide offenders, regardless of the date when the offence was committed, unless the offender was convicted before the date of commencement or the court accepted a plea of guilty which was not withdrawn before that date. Section 28 now provides so far as relevant to VISs from family victims:

(3) If the primary victim has died as a direct result of the offence, a court must receive a victim impact statement given by a family victim and acknowledge its receipt, and may make any comment on it that the court considers appropriate.

(4) A victim impact statement given by a family victim may, on the application of the prosecutor and if the court considers it appropriate to do so, be considered and taken into account by a court in connection with the determination of the punishment for the offence on the basis that the harmful impact of the primary victim's death on the members of the primary victim's immediate family is an aspect of harm done to the community.

(4A) Subsection (4) does not affect the application of the law of evidence in proceedings relating to sentencing.

Subsection (3) is unchanged from the former law. Subsection (4A) is an entirely new provision which appears designed to enable the cross-examination

51 See, eg, Amy Dale, 'Ray Hadley Slams “Weak-Kneed” Justice System for King-Hit Killer Kieran Loveridge's Four-year Jail Term', The Daily Telegraph (online), 8 November $2013<\mathrm{http}: / /$ www.daily telegraph.com.au/ray-hadley-slams-weakkneed-justice-system-for-kinghit-killer-kieran-loveridgesfouryear-jail-term/news-story/3886b0b019dbf52b350f57351811412d $>$.

$52 \quad R v$ Loveridge (2014) 243 A Crim R 31, 66 [280], 66-7 [282] (The Court).

53 Ibid 46 [109], 48 [129], 59 [217]-[218], 61 [230].

54 Ibid $46[105]$.

55 Ibid 43-4 [90]. 
of family victims on their VIS. Previously courts had taken the view that victims could not be cross-examined on their statements..$^{56}$

Key changes to the law are located in subsection (4). The former provision stipulated that the court 'must not' take account of VISs from family victims unless it considered it appropriate to do so. Under the new law, a sentencing court 'may' take account of a VIS by a family victim in the determination of the penalty, on the basis that the harmful impact on the deceased's family is an aspect of harm done to the community, provided that:

- The prosecution makes an application that the court does take account of the VIS; and

- The court considers it appropriate to do so.

Aside from the change in language from the mandatory 'must not' to the discretionary 'may', with regard to taking account of VISs in particular circumstances, a significant change is the express link made between the contents of VISs from family victims to the sentencing purpose as set out in section $3 \mathrm{~A}(\mathrm{~g})$ of the CSPA to recognise the harm done to the community. It is also significant that the test of 'appropriateness' has been retained although, as was the case with the law it replaces, the legislature provides no guidance in relation to the application of the test. In a similar vein, the legislation does not clarify how VISs are to be taken into account or what weight is to be afforded to them in the process. These remain matters for the courts. The next section considers the application and the interpretation of the new law.

\section{Application and Interpretation of the New Law}

This section draws on a case study of 39 murder or manslaughter sentencing judgments handed down by the NSW Supreme Court between 1 July 2014 and 13 April 2017, and one appellate decision, Sumpton v The Queen [2016] NSWCCA 162 ('Sumpton'), that addresses the new law. Judgments included in the case study were identified from searches of two databases - Austlii and BarNet Jade. Purposive sampling techniques were used to select judgments for inclusion in the case study. ${ }^{57}$ The criteria for inclusion were: the offender was sentenced for a homicide offence in the NSW Supreme Court; 58 the new law applied to sentencing the offender (given the date of a guilty plea and/or conviction following trial); ${ }^{59}$ and VISs were submitted by family victims. ${ }^{60} \mathrm{~A}$ total of 71 judgments meeting these criteria were identified during the relevant time period and all of these judgments were originally included in the case study. Each judgment was analysed using a doctrinal approach to determine how the

$56 \quad R v$ Wilson [2005] NSWCCA 219, [27] (Simpson J).

57 David Silverman, Doing Qualitative Research (Sage, $3^{\text {rd }}$ ed, 2010) 141-3.

58 In this context, 'homicide offence' means murder or manslaughter.

59 Whether or not the new law applied was determined by the relevant dates of a guilty plea or conviction after trial revealed in the sentencing judgments.

60 Whether family victims submitted a VIS in a particular case was determined according to whether the VIS was referred to in the sentencing judgment. Judgments were only included if a sentencing judge indicated on the face of the judgment that a VIS was submitted. 
new law was interpreted and applied, and in particular whether and, if so how, the sentencing court used the VIS to formulate penalty. Initial analysis revealed however that the prosecution did not apply to have the VISs taken into account in all of these matters. In fact, prosecution applications were expressly noted in only 39 decisions ${ }^{61}$ In another eight matters, ${ }^{62}$ the sentencing judges expressly noted that the prosecution did not make such an application; in those latter cases, the sentencing judges treated the VISs in accordance with the former law and expressly stated that the VISs were not taken into account. There was no reference to a prosecution application or the provisions of the new law in the remaining 24 matters; in those cases, the VISs were acknowledged by the sentencing judge generally with reference to the justice principles in Previtera and with no indication as to the use of those statements in determining penalty. For example, in $R v$ Kahn, Fullerton J said:

By receiving their statements and inviting then to be read, the Court recognises the far reaching and substantial impact of the deaths of the deceased on all their family members. Their understandable suffering cannot, however, influence the sentences [to be imposed] ... The law does not differentiate between the value of life lost or permit a sentencing judge to factor into an otherwise appropriate sentence any additional penalty because a deceased person was loved and surrounded by family and friends who have suffered through their death. It is the criminal culpability in the taking of life itself that is the departure point for the appointment of criminal punishment. ${ }^{63}$

For the purposes of gathering data on the interpretation and application of the new law by sentencing courts, the case study ultimately comprised only those matters where the prosecution applied to have the VISs taken into account in sentencing $(n=39)$.

If VISs are to be taken into account under the new law, it is on the basis that the harm sustained by the family victims is an aspect of harm done to the community. Shortly after the new law commenced some sentencing courts articulated a specific connection between the harm suffered by the family victims and harm to the community in the particular circumstances ${ }^{64}$ For instance, in $R v$ Hines [No 3] the sentencing judge addressed the family victims as follows in his sentencing judgment:

your harm is an aspect of the community's harm. Alan Hines, through his senior counsel and experienced solicitor, agrees that I should take it into account. He recognizes that Aaron [the deceased] was the father of two little girls, one of whom is severely disabled and that the whole community will be affected in the long run by the care required for Ashantie. He acknowledges that Wilcannia is a

61 There is no indication in the judgments that the applications were opposed.

$62 R v A N$ [2014] NSWSC 1879; $R$ v Beattie [No 4] [2015] NSWSC 961; $R$ v Hadchiti [2017] NSWSC 292;

$R v J H$ [2014] NSWSC 1878; $R v$ Lambaditis [2015] NSWSC 746; $R v$ Perkins [2016] NSWSC 1080;

$R v S B$ [2015] NSWSC 659; $R v$ Silva [2015] NSWSC 148. It is important to note that this might well have been the case in other matters but, for the purposes of this analysis, only those cases where it was expressly stated in the sentencing judgment that the Crown did not make an application have been counted.

63 [2016] NSWSC 1073, [50].

$64 R v$ Hines [No 3] [2014] NSWSC 1273, [75]-[76] (Hamill J) ('Hines [No 3]'); $R v$ Barbieri [2014] NSWSC 1808, [11] (Hulme J). 
small, close-knit community and that Aaron was admired as a good football player and young member of that community. ${ }^{65}$

The case study data reveal however the emergence of a line of authority whereby it is not necessary to articulate a specific connection in each case in order for the harm sustained by the family victims to be regarded as an aspect of harm done to the community. In $R v$ Halloun McCallum J said:

I would construe the new provision as an important mechanism for ensuring that the evidence of family victims is placed before the court to give texture to the undoubted proposition that every unlawful taking of a human life harms the community in some way. In that way, the provision serves the purposes of sentencing stated in s $3 \mathrm{~A}$ of the Act, one of which is to recognise the harm done to the victim of the crime and the community. ${ }^{66}$

Halloun was cited with approval by the CCA in Sumpton ${ }^{67}$ In the latter case, the appellant appealed against sentence on the basis that the sentencing judge had wrongly assessed the objective seriousness of the offence as being "comfortably above the middle range' and the penalty imposed was too high. ${ }^{68}$ One submission in support of the appeal related to the sentencing judge's use of VISs. ${ }^{69}$ At sentencing, in response to the prosecution's application under section 28(4) for the sentencing judge to take account of the VISs in determining penalty, the offender had conceded that the harm done to the deceased's family revealed by the VISs was an aspect of harm done to the community. In these circumstances, the sentencing judge described the concessions as 'sensible' and found it was appropriate to take the VISs into account in sentencing. ${ }^{70}$

On appeal, the appellant submitted that section 28(4) was only 'technically applicable" and the reference to "harm done to the community" had no real application, and was not deserving of any weight'. ${ }^{71}$ The CCA found however that the sentencing judge had not erred in 'in his assessment of the objective seriousness of the offending' ${ }^{72}$ Bellew $\mathrm{J}$, with whom the other members of the appeal Court agreed, said that the offender's concession to take account of the harm done to the deceased's family was appropriate and consistent with authority, citing Halloun (extracted above) with approval. ${ }^{73}$ His Honour also approved the following observation made by Johnson $\mathrm{J}$ in $R v$ Pluis:

I accept that the harmful impact of the offence upon the primary victim's immediate family is an aspect of harm done to the community in this case. Under the law, all lives are precious and the death of any person is a harm inflicted on the community in general ... Harm to the community is always caused when an innocent life is taken, but the way in which the harm is felt varies. ${ }^{74}$

\footnotetext{
65 [2014] NSWSC 1273, [75] (Hamill J).

66 [2014] NSWSC 1705, [46] ('Halloun').

67 [2016] NSWCCA 162, [153] (Bellew J).

68 Ibid [125]-[130], [132]-[139].

69 Ibid [136]-[139].

$70 \quad R$ v Sumpton [No 4] [2015] NSWSC 684, [43] (Hamill J).

71 Sumpton [2016] NSWCCA 162, [139].

72 Ibid [156] (Bellew J).

73 Ibid [153].

74 [2015] NSWSC 320, [103] ('Pluis'), quoted in ibid [155].
} 
Sumpton is authority for the principle that the harm caused to family victims as a result of the death of the primary victim is an aspect of harm done to the community and relevant to the assessment of the objective circumstances of sentencing. There is no need to establish in each case a connection between the particular harm sustained by family victims as detailed in the VISs and the ensuing harm done to the community. Furthermore, the statement in Pluis above that '[h]arm to the community is always caused when an innocent life is taken' suggests that there is no need for the harm sustained by the family victims to meet a particular 'standard' in order to amount to harm done to the community.

The case study data were also analysed in relation to the use of VISs in the determination of penalty. In the majority of matters $(n=23)$, sentencing judges expressly 'took account of' the harmful impact of the deceased's death evidenced by their VISs as an aspect of harm done to the community though there was no indication of what weight, if any, was afforded the VIS in the process. ${ }^{75}$ For example, in $R v$ Haines Hulme AJ said:

Almost invariably the violent death of a family member imposes suffering on near relatives. Nevertheless, I accept that it is appropriate to take the suffering evident in the Victim Impact Statements into account in determining the appropriate sentence and I will do so. ${ }^{76}$

Conversely, the sentencing judge in $R v$ Towney [No 2] who took account of the VIS, stipulated that the VIS was not an aggravating factor; rather it reflected harm that was inherent in the offence of murder as committed in the circumstances of that case. ${ }^{77}$ Similarly, in three further matters, the sentencing judges also took account of the VISs in sentencing but each stated expressly that the VIS did not influence the ultimate penalty imposed on the offender. ${ }^{78}$ For example, in Spicer, Harrison J said that in taking account of the VISs he wished to make clear: 'that I would have imposed the sentence that I intend to impose even if the statements from Mr and Mrs Foreman had not been provided to the court'. ${ }^{79}$

While taking account of the VISs in sentencing, judges in another eight matters responded to the issue of appropriateness under the new law by reiterating the justice concerns expressed in Previtera and in particular the view

$75 \quad R v$ Abdallah [2015] NSWSC 531; $R$ v Barbieri [2014] NSWSC 1808; $R$ v Briggs [No 9] [2014] NSWSC $1805 ; R v$ Do [No 4] [2015] NSWSC 512; $R$ v Droudis [No 16] [2017] NSWSC 20; $R v$ Fang [No 4] [2017] NSWSC 323; $R v$ Haines [2015] NSWSC 390; $R$ v Haines [No 3] [2016] NSWSC 1812; $R v$ Hart [No 5] [2016] NSWSC 1612; $R$ v Hunter [No 15] [2014] NSWSC 1456; $R$ v Johnson [2015] NSWSC 31; $R v$ Jones [No 3] [2014] NSWSC 1511; $R$ v Kelsall [2015] NSWSC 480; $R$ v KJ [2015] NSWSC 767; $R v$ Lane [No 3] [2015] NSWSC 118; $R$ v Matthews [2015] NSWSC 49; Patel [No 2] [2015] NSWSC 1381; Plius [2015] NSWSC 320; $R$ v Quinn [No 3] [2016] NSWSC 1699; $R$ v Serutawake [2014] NSWSC 1762; $R v$ Sumpton [No 4] [2015] NSWSC 684; $R v$ Wang [2016] NSWSC 222; $R v$ Wong [2015] NSWSC 1612.

76 [2015] NSWSC 390, [37] (Hulme AJ).

77 [2016] NSWSC 97, [57] (Fagan J).

$78 \quad R v$ D'Ambrosio [2014] NSWSC 1685, [42]; $R$ v Dyer [2014] NSWSC 1809, [11]; $R$ v Spicer [2015] NSWSC 519, [91] ('Spicer').

79 [2015] NSWSC 519, [91]. 
that one life cannot be valued more highly than another. ${ }^{80}$ In Hines [No 3] for example, his Honour noted the lack of guidance in the new law as to when it is appropriate to take account of VISs and, referring to the justice concerns expressed in Previtera, he said:

The reality is that homicide and other crimes where people are killed have devastating and long-term effects in every case. The exception may be a friendless or homeless member of the community. Is the law to regard a homeless, unloved person's life as less valuable than another's? This strikes me as being philosophically offensive. ${ }^{81}$

McCallum $\mathrm{J}$ also referred to the lack of guidance in the new law in Halloun and said: 'It seems unthinkable that the amendment reflects an acceptance by the legislature that some lives are more valuable to the community than others' ${ }^{82} \mathrm{As}$ already noted above, on her Honour's interpretation of the provision, VISs are used to recognise harm caused to family victims and 'give texture' to the proposition that harm suffered by the family victim also harms the community. McCallum J's interpretation of the provision was expressly adopted in four subsequent decisions included in this case study ${ }^{83}$

In a marked departure from the previous law, the sentencing judges in two of the 39 matters where the prosecution made an application used the VISs from family victims as evidence of an aggravating factor, substantial emotional harm under section $21 \mathrm{~A}(2)(\mathrm{g})$ of the CSPA. ${ }^{84}$ These cases will be discussed in further detail below.

Prosecution applications were unsuccessful in two cases. In $R v$ Aller [No 2], the sentencing judge noted that the prosecution application was not developed beyond a reference to the new law and ruled that it was not appropriate to take the VISs into account in determining the limiting term. ${ }^{85}$ In $R v$ Merrick [No 5], the prosecution submitted that the VISs should be used in determining penalty because the harm sustained by family victims in losing their mother was more serious, or 'elevated', than would normally be anticipated. ${ }^{86}$ In response, the offender argued that although the loss to the deceased's family was 'considerable ... the children are well supported, and their loss is mitigated to some degree by the family love with which they are surrounded' ${ }^{87}$ The sentencing judge found that the VISs did not 'worsen the offender's crime'; rather the VISs were 'demonstrative of the harm that is inherent in an offence of manslaughter, and

$80 R v$ Grogan [2017] NSWSC 378, [22] (Hidden AJ); Halloun [2014] NSWSC 1705, [46] (McCallum J); Hines [No 3] [2014] NSWSC 1273, [78]-[84] (Hamill J); $R$ v Jenbare [2016] NSWSC 1317, [46] (McCallum J); $R$ v Johnson [2015] NSWSC 31, [55] (Hamill J); $R$ v Martin [2015] NSWSC 521, [170] (Schmidt J); $R$ v Murray [2015] NSWSC 1034, [122] (Schmidt J); $R$ v Payam [2015] NSWSC 1819, [35] (Mathews AJ).

81 [2014] NSWSC 1273, [84] (Hamill J).

82 [2014] NSWSC 1705, [46].

$83 R v$ Grogan [2017] NSWSC 378, [22] (Hidden AJ); $R v$ Jenbare [2016] NSWSC 1317, [49] (McCallum $\mathrm{J}) ; R v$ Johnson [2015] NSWSC 31, [56] (Hamill J); $R$ v Payam [2015] NSWSC 1819, [35] (Mathews $\mathrm{AJ})$.

$84 \quad R v$ Breen [2015] NSWSC 1757, [41] (Mathews AJ); $R$ v Anderson [2016] NSWSC 399, [105] (Hall J).

85 [2015] NSWSC 402, [13] (Hidden J).

86 [2016] NSWSC 661, [63] (Wilson J).

87 Ibid [64] (Wilson J). 
should be viewed consistently with the principles expressed in $R v$ Previtera' ${ }^{8} 8$ Furthermore:

An assessment of that nature would involve the sentencing courts in an evaluation of the value of an individual life, measured by the pain and loss caused by the death. By that exercise, for example, the unlawful killing of a skilled doctor could be regarded more seriously than the unlawful killing of someone without those skills. That is an assessment no court should undertake in my view, because the gravity of the crime is the unlawful taking of a human life. ${ }^{89}$

The case study reveals that despite the opportunities provided by the new law, the VISs were not generally used to increase the penalty imposed on the offender. While the VISs were said to be taken into account in the vast majority of sentencing judgments in the case study, there was no indication of the weight, if any, attached to the statements in the process. As already noted, the legislature does not clarify how VISs are to be taken into account, the weight to be afforded to them in this process, and these questions were not addressed by the CCA in Sumpton. In this regard, it is highly significant that the VISs were expressly used as evidence of an aggravating factor in only two of the 39 judgments (8 per cent). It is also noteworthy that the justice issues raised by Previtera continued to resonate in at least nine of the 39 judgments (over 25 per cent).

Overall, the case study data indicate that in more than 90 per cent of matters, the new law did not substantially change the sentencing courts' approach to the use of VISs in the sentencing of homicide offenders. The harm suffered by family victims and the community was regarded as intrinsic to the nature of homicide offending, anticipated by the sentencing court and taken into account in sentencing as part of the objective circumstances of the offence. The objective circumstances of the offence together with the personal circumstances of the offender and any other relevant factors formed the mix from which, by a process of instinctive synthesis, the judge determined the appropriate penalty proportionate to the offending. It is clear that this approach is very similar to the approach under the former law examined above. And indeed, this point was recognised by the CCA in Sumpton where Davies J's observation in $R v D o$ [No 4] was quoted with approval: 'It is far from clear what practical difference has been made by the amendment'.$^{90}$

It is contended that the contentious nature of VISs as evidential devices generally, and more specific concerns regarding VISs as evidence of aggravating factors in the context of homicide sentencing, are two key issues that have underpinned the courts' approach to the new law. These issues will be addressed in the following two sections.

\section{The Evidential Status of VISs}

The evidential status of VISs has been a source of controversy in nonhomicide cases and, traditionally, the courts have approached the use of VISs as

88 Ibid [67] (Wilson J).

89 Ibid [66] (Wilson J).

90 [2015] NSWSC 512, [50], cited in Sumpton [2016] NSWCCA 162, [154] (Bellew J). 
evidence of harm caused by the offence 'with caution and a critical eye'. ${ }^{91}$ Concerns about the quality of VISs as evidence of harm in sentencing reflect the disjuncture between the traditional and respected 'legal' forms of evidence and the subjective and unconventional nature of VISs. ${ }^{92}$ From a legal perspective, VISs are a 'particular species of evidence' that is not equivalent to prosecution evidence; ${ }^{93}$ they are not submitted by a party to the proceedings, and they are not submitted in a recognised legal form. In NSW, written VISs are not sworn documents and oral VISs are not presented under oath or affirmation. A VIS is presented as a narrative rather than in the conventional question and answer format. There are limited opportunities for the offender to test the veracity of the contents of the statement and penalties are not imposed on victims if their statements are untrue. These issues are complicated by the fact that VISs are not 'objective' statements of harm. ${ }^{94}$ Research has shown that VISs by family victims are highly personal, subjective narratives of suffering experienced by the deceased's family. ${ }^{95}$

Generally, the use of VISs is unproblematic for the courts when the harm described in the VIS reflects the nature and extent of harm that would be an anticipated consequence of the offending and/or it is conceded by the offender. More problematic are those cases where the issue is whether a VIS can be used as evidence of unanticipated harm and/or an aggravating factor. Aggravating factors must be proved beyond reasonable doubt unless conceded by the offender, ${ }^{96}$ and one commentator has argued in relation to the new law that it will be difficult to use VISs from family victims as evidence of aggravating factors because it is unlikely that those VISs could meet this 'strict standard'. ${ }^{97}$

Whether or not VISs can be used as evidence to prove an aggravating factor has been the subject of debate before the CCA in the context of non-homicide offences. ${ }^{98}$ Justice Wood's much-quoted warning in relation to the use of VISs for this purpose in $R v$ Berg is apposite:

I would sound a note of caution in relation to the proper approach to fact-finding concerning the impact of a crime upon other members of the community or, upon the victim. If that is to be achieved by way of victim impact statements, then an

91 Booth, Accommodating Justice, above n 2, 43.

92 Ibid; Ashworth, above n 3, 507; Ian Edwards, 'The Evidential Quality of Victim Personal Statements and Family Impact Statements’ (2009) 13 International Journal of Evidence and Proof 293.

$93 R v$ Wilson [2005] NSWCCA 219, [25] (Simpson J).

94 Samuel Burton, 'Changes to the Law Concerning Victim Impact Statements in NSW' (2014) 1 Law Society of NSW Journal 66, 67.

95 Booth, Accommodating Justice, above n 2, 23-34; Christine M Englebrecht and Jorge M Chavez, "Whose Statement Is It? An Examination of Victim Impact Statements Delivered in Court' (2014) 9 Victims and Offenders 386, 394-400, 402-4; Paul Rock, 'Hearing Victims of Crime: The Delivery of Victim Impact Statements As Ritual Behaviour in Four London Trials For Murder and Manslaughter' in Anthony Bottoms and Julian V Roberts (eds), Hearing the Victim: Adversarial Justice, Crime Victims and the State (Routledge, 2011) 200, 205-7, 211-14, 216-17.

$96 \quad R$ v Olbrich (1999) CLR 270, 281 [27] (Gleeson CJ, Gaudron, Hayne and Callinan JJ); $R v$ Wickham [2004] NSWCCA 193, [27] (The Court); $R$ v Tuala (2015) 248 A Crim R 502, 511 [40] (Simpson J) ('Tuala').

97 Burton, above n 94, 67.

98 See, eg, Ollis $v$ The Queen [2011] NSWCCA 155, [86]-[93]; RP v The Queen (2013) 234 A Crim R 272, $275-8$ [17]-[31]. 
injustice may occur in relation to a person standing for sentence, in so far as the maker of the statement would not normally be available for cross-examination. ... extreme care needs to be taken by those who prosecute and defend these cases, and also by trial Judges in always ensuring that there is a proper evidentiary basis for any findings of fact which go towards aggravating or mitigating a sentence. ${ }^{99}$

This issue was considered by the CCA in its recent decision, Tuala. Tuala shot at the victim at close range three times and was convicted of the discharge of a firearm with intent to cause grievous bodily harm. At sentencing, the victim submitted a VIS claiming he had sustained significant and continuing physical, psychological, emotional and financial harms as a result of the offence. While the offender did not object to the admission of the VIS, he did submit that it could not be relied upon because the victim 'was not a truthful person', and 'the Court should take with some scepticism what [the victim] says'. ${ }^{100}$

The prosecution appealed against the manifest inadequacy of the sentence imposed and relied on the VIS to argue that the victim had sustained substantial harm that amounted to an aggravating factor. Accordingly, the issue for the CCA was whether or not an unsworn VIS, not tested by cross-examination, could prove harm that goes beyond that which 'would ordinarily be expected of the offence charged', to the requisite standard - beyond reasonable doubt. ${ }^{101}$ Simpson $\mathrm{J}$ (with whom the other members of the Court agreed) found that VISs could provide such evidence though 'each case will depend on its own facts and circumstances'. ${ }^{102}$ Relevant facts and circumstances to be considered by the sentencing court in this context include:

- the manner in which the hearing was conducted - that is, whether the VISs were admitted with or without objection and/or whether the offender made submissions as to the weight to be attached to the statement;

- the credibility of the victim's account in the VIS in light of their own or other evidence at the trial and consistency with other relevant evidence such as an agreed statement of facts; and

- the existence of corroborative evidence in more traditional legal forms such as expert reports. ${ }^{103}$

Her Honour warned however that 'considerable caution must be exercised before the victim impact statement can be used to establish an aggravating factor to the requisite standard' in cases where:

- the facts to which the [VIS] attests are in question; or

- the credibility of the victim is in question; or

- the harm which the statement asserts goes well beyond that which might ordinarily be expected of that particular offence; or

- the content of the [VIS] is the only evidence of harm. ${ }^{104}$

99 [2004] NSWCCA 300, [48]-[49].

100 Tuala (2015) 248 A Crim R 502, 508-9 [25]-[26] (Simpson J).

101 Ibid 514-15 [57] (Simpson J).

102 Ibid 513 [51] (Simpson J). See also Bajouri v The Queen [2016] NSWCCA 20, [39]-[41].

103 Tuala (2015) 248 A Crim R 502, 519 [78]-[80]. 
Ultimately, in the circumstances of Tuala, which included the fact that the offender had made submissions during the sentencing hearing regarding the weight to be given to the VIS, the Court ruled that the VIS could not be used to prove harm more substantial than that which could ordinarily be expected. The sentencing judge's assessment that the victim was not a particularly credible witness meant that 'doubt must attend his assertion of financial loss and ongoing disability'. ${ }^{105}$

Subject to the facts and circumstances of the case, it is clear from Tuala that VISs can provide evidence of harm that amounts to an aggravating factor to the requisite standard. The next section turns to consider the specific issues that arise in relation to the use of VISs from family victims as evidence of an aggravating factor in sentencing homicide offenders under the new law.

\section{VISs As Evidence of Aggravation in Homicide Matters}

Section $21 \mathrm{~A}(2)(\mathrm{g})$ of the CSPA provides that a sentencing court must take into account substantial 'injury, emotional harm, loss or damage caused by the offence' as an aggravating factor. Given the nature of harm suffered by family victims, substantial emotional harm under this provision is the aggravating factor most likely to be raised in homicide cases. ${ }^{106}$ Harm will be 'substantial' for the purposes of this provision when it is significantly more serious than that which an 'ordinary' person would have suffered when subjected to the same or similar offence. ${ }^{107}$ In Huynh $v$ The Queen, the CCA explained further that 'emotional harm qualified by the adjective substantial may be taken to be a reference to an appreciable psychological injury whether permanent or not. It refers to something more than the transient, or temporary' ${ }^{108}$ However, as pointed out by the CCA in Elyard v The Queen, the legislation does not make clear how the provision is to be applied, ${ }^{109}$ though it should be noted that under section $21 \mathrm{~A}(5)$ the presence of an aggravating factor need not necessarily lead to a more severe penalty.

The case study revealed two cases where VISs from family victims were used as evidence of substantial emotional harm and an aggravating factor under section $21 \mathrm{~A}(2)(\mathrm{g}) .{ }^{110}$ The offender in the first of these cases, Breen, killed his father and step-mother in a particularly violent manner in front of their young children and was on his way to kill other family members including his mother when he was apprehended. ${ }^{111}$ Several VISs were submitted by family victims detailing extensive emotional and psychological trauma including: post-traumatic stress disorder; self-harm; suicidal thoughts; depression; anxiety; and guilt. ${ }^{112}$ The sentencing judge described the offender's mother as 'intensely traumatised',

104 Ibid 519 [80]-[81] (Simpson J).

105 Ibid 519 [83] (Simpson J).

106 See, eg, ibid 508 [23]-[24] (Simpson J).

$107 R$ v Youkhana [2004] NSWCCA 412, [26] (Hidden J); $R$ v Solomon (2005) 153 A Crim R 32, 36 [17] (Howie J).

108 [2015] NSWCCA 179, [29] (Campbell J) (emphasis in original).

109 [2006] NSWCCA 43, [5] (Basten JA).

$110 \quad R v$ Breen [2015] NSWSC 1757 ('Breen'); $R$ v Anderson [2016] NSWSC 399 ('Anderson').

111 [2015] NSWSC 1757, [24]-[28] (Mathews AJ).

112 Ibid [70]-[73] (Mathews AJ). 
'constantly haunted by the realisation that her son was coming to kill her', and noted her VISs expressed 'overwhelming trauma'. ${ }^{113}$ For the judge, '[s]imply listening to and reading these statements is a distressing experience in itself'. ${ }^{114}$ The Court used the VISs as evidence of emotional harm that was so substantial as to go "well beyond what would be expected as ... "normal"', constituting an aggravating factor that is 'inherent in the offence of murder'. ${ }^{15}$ In making this evaluation, the judge did not articulate the expected level of emotional harm sustained by family victims, remarking, 'if indeed there is such a thing as a normal consequence in relation to this offence'. ${ }^{116}$

In the second case, Anderson, the offender was convicted of excessive selfdefence manslaughter of his former partner. ${ }^{117}$ At the time of her death, the deceased was five to six months pregnant with the offender's child. The sentencing judge described the VIS submitted by the deceased's mother as expressing:

in very clear terms the grievous effect and the immense loss arising from the death of her daughter ... and the impact it has had upon the members of her family. The loss of a loved one, in the circumstances with which this case is concerned, is exceptionally painful and tragic. ${ }^{118}$

The Court found that the VIS provided evidence of substantial emotional loss and damage 'caused in particular to the deceased's mother and family, by her daughter's death involving as it did the loss of her daughter's unborn child'. ${ }^{119}$ This harm went 'beyond the emotional harm or loss that might otherwise have been expected' ${ }^{\prime 20}$ although, similar to Breen, the expected consequences of the offending were not established.

An important caveat to the application of section $21 \mathrm{~A}(2)(\mathrm{g})$ is that the harm alleged to be so substantial cannot be taken into account as an aggravating factor if it is already an element or 'an inherent characteristic' of the offence. ${ }^{121}$ If the harm that is the subject of enquiry is an element or an inherent characteristic of the offence, then it is part of the objective circumstances or seriousness of the offence. The maximum penalty (and minimum non-parole period if relevant) indicates the seriousness with which the legislature views a particular crime and that seriousness reflects the core elements and inherent characteristics of the offending. ${ }^{122}$ To take that harm into account as an aggravating factor is to risk 'double counting' and amount to a sentencing error. ${ }^{123}$

113 Ibid [69], [71] (Mathews AJ).

114 Ibid [69] (Mathews AJ).

115 Ibid [41], [74] (Mathews AJ).

116 Ibid [74] (Mathews AJ).

117 [2016] NSWSC 399, [1]-[6] (Hall J).

118 Ibid [103] (Hall J).

119 Ibid [105] (Hall J).

$120 \operatorname{Ibid}($ Hall J).

121 Elyard $v$ The Queen [2006] NSWCCA 43, [40] (Howie J).

122 GAL [2015] NSWCCA 242; Elyard $v$ The Queen [2006] NSWCCA 43; $R v$ Youkhana [2004] NSWCCA 87; Josefski (2010) 217 A Crim R 183.

123 GAL v The Queen [2015] NSWCCA 242, [34] (The Court); Elyard v The Queen [2006] NSWCCA 43, [40] (Basten JA); R v Youkhana [2004] NSWCCA 412; Josefskiv The Queen (2010) 217 A Crim R 183, $196[45]$ (Howie J). 
The emotional harm suffered by family victims as a result of the death of the primary victim is an inherent characteristic of a homicide offence and thereby relevant to the assessment of the objective seriousness of the offending. It is also clear that given the nature and seriousness of homicide offending, the emotional harm suffered by family victims is likely to be substantial. Homicide offences are among the most serious offences in NSW. The maximum penalties for murder and manslaughter in particular are severe and convey the extreme seriousness with which the legislature regards homicide offending. To the extent that VISs from family victims describe the consequences of the killing for the deceased's family, the devastating loss, suffering and trauma, they reflect substantial emotional harm that is intrinsic to the nature of homicide offending and exemplify why the taking of a human life is such a serious offence. $R v$ Birmingham [No 2] provides an example of this argument. There, the South Australian Supreme Court found that in the circumstances of the offending, the harm sustained by the family victims and detailed in their VISs was of a nature and extent to be anticipated and not an aggravating factor:

given the youth of the deceased and the circumstances of his death, the grief and outrage felt by the surviving parents is very much what I might have expected, even if I had not had the benefit of the victim impact statements ... It follows that even without the benefit of those statements, I doubt that I would have imposed a less severe sentence. ${ }^{124}$

A finding that a VIS from a family victim is evidence of harm so serious that it amounts to an aggravating factor requires the sentencing court to find that the depth of suffering revealed by the VISs exceeds the suffering already anticipated and intrinsic to the seriousness of the offence. While the sentencing courts in both Breen and Anderson found the harm suffered to be substantial, they did not articulate the 'normal' level of emotional harm caused to family victims by homicide offending (that is, intrinsic to the offence). However, it appears that the law does not require sentencing courts to establish the anticipated or 'normal' level of harm in order to find the harm suffered in a particular case is substantial. ${ }^{125}$ Indeed, in Muggleton, the CCA found that it was unnecessary to establish the normal level of harm because 'plainly [the victim's response was] greater than one would expect'. ${ }^{126}$ This approach is not surprising given the extreme difficulty of articulating a standard and any such evaluation of harm will be a 'value judgment' drawn from the sentencing judge's life experience and expertise.

If the court relies on VISs from family victims to establish substantial emotional harm so as to amount to an aggravating factor, it is evident then that there is a significant risk of double counting the harm sustained by family victims in homicide offences. Indeed, this risk was acknowledged by the sentencing judge in Anderson, who, having used the VIS to prove an aggravating factor, found that the VIS could not also be taken into account under section 28(4) of the CSPA: 
Having accepted the emotional harm of the deceased's family as an aggravating factor pursuant to section 21(2)(g), to grant the Crown Prosecutor's application under section 28(4) ... to take [the VIS] into account in the determination of punishment would, in my opinion, be to carry an unacceptable risk of doublecounting. ${ }^{127}$

It is argued however that because the emotional harm sustained by the family victims is an inherent characteristic of the nature of the offending, it was already a factor in the objective seriousness of the offence before it was taken into account as an aggravating factor. Therefore, not taking account of the VIS did not avoid the risk of double counting.

Not only might these difficulties presented by section $21 \mathrm{~A}(2)(\mathrm{g})$ constrain the use of VISs as evidence of aggravating factors in the context of homicide sentencing, but the case study shows that the principle in Previtera continues to resonate for several members of the NSW Supreme Court. Following Previtera, sentencing courts did not consider it appropriate to take account of VISs from family victims as an aggravating factor because to do so required the court to evaluate the depth and strength of family victims' suffering at the loss of a loved family member. ${ }^{128}$ Such an evaluation requires the court to engage in a comparative exercise to determine if the suffering described by the VISs in a particular case is deeper, more acute, and more serious than that expressed in another case. ${ }^{129}$ This process could involve invidious comparisons and carry a risk that, inconsistent with principles of equality and justice, the ultimate penalty could reflect the worthiness and perceived 'value' of the deceased rather than the culpability of the offender. Sentencing judges in several matters within the case study (and also several matters excluded from the case study [see above]) reiterated the justice concerns expressed in Previtera. $R v$ Merrick [No 5], discussed above, provides a salient example of these concerns. It will be recalled that in that case, the judge declined the prosecution's application, and in response to the competing assessments of the harm sustained by the family victims proffered by the parties, said:

Those competing submissions to some extent illustrate why courts sentencing offenders for an offence involving death have consistently refused to delineate the particular harm caused by an individual's death. That exercise involves the Court putting a value on the life of the individual. Here, the Crown argued that the harm caused by [the deceased's] death was elevated because she was the mother of three children; the offender's representative sought to diminish the harm by arguing that the children had others to care for and support them. In my view, determining competing arguments of that nature is something that the courts should avoid. ${ }^{130}$

Though these justice concerns have been the subject of a well-documented debate under the former law, ${ }^{131}$ these concerns have yet to receive appellate

127 [2016] NSWSC 399, [105] (Hall J).

128 Susan A Bandes and Jessica M Salerno, 'Emotion, Proof and Prejudice: The Cognitive Science of Gruesome Photographs and Victim Impact Statements’ (2014) 46 Arizona State Law Journal 1003, 1037. Ibid.

130 [2016] NSWSC 661, [65] (Wilson J).

131 Tracey Booth, 'Penalty, Harm and the Community: What Role Now For Victim Impact Statements in the Sentencing Of Homicide Offenders in NSW?' (2007) 30 University of New South Wales Law Journal 
consideration in the context of the new provisions. This uncertainty aside however, it is argued that the application of section $21 \mathrm{~A}(2)(\mathrm{g})$ limits the use of VISs as evidence of an aggravating factor to only very rare cases. The implications of these findings for family victims will be considered in the next section.

\section{THE IMPLICATIONS OF THE NEW LAW FOR FAMILY VICTIMS}

This section will address the implications for family victims in relation to both instrumental and expressive functions of VISs in sentencing homicide offenders.

\section{A Instrumental Function}

The foregoing reveals that while under the new law sentencing courts are more likely to expressly take account of VISs from family victims as an aspect of harm done to the community, it is arguable that this does not represent a shift in practice and will not enhance the role of VISs in sentencing homicide offenders. Under the former law, harm to family victims was an inherent characteristic of the nature and seriousness of homicide offending and therefore part of the objective seriousness of the offence. The new law does not change this position. What does appear to have changed is the potential for VISs to be used as evidence of harm that amounts to an aggravating factor. However, as has been demonstrated, such use of VISs is particularly problematic in the context of homicide offending and it will be in only very rare cases that the emotional harm suffered by family victims is so substantial as to exceed the already very substantial harm intrinsic to the offending. As a result, it is contended that the practical operation of the new law will not change the way in which VISs from family victims are used in sentencing, and in the vast majority of matters those VISs will not be used to increase the penalty imposed.

This conclusion raises the issue of family victims' expectations of the impact of their VISs. A key criticism of VIS legislation generally has been that the practical operation of the law does not necessarily meet victim expectations thereby generating anger, frustration, distress, and victim dissatisfaction with sentencing. ${ }^{132}$ The official information about VISs available to victims through

664; Tyrone Kirchenghast, 'Sentencing Law and the "Emotional Catharsis" Of Victim's Rights in NSW Homicide Cases' (2008) 30 Sydney Law Review 615; Julian V Roberts and Marie Manikis, 'Victim Impact Statements at Sentencing: The Relevance Of Ancillary Harm' (2010) 15 Canadian Criminal Law Review 1; Bandes and Salerno, above n 128.

132 Edna Erez and Pamela Tontodonato, 'Victim Participation in Sentencing and Satisfaction with Justice' (1992) 9 Justice Quarterly 393; Edna Erez, Leigh Roeger and Frank Morgan, 'Victim Impact Statements in South Australia: An Evaluation' (Series C No 6, Office of Crime Statistics, South Australian AttorneyGeneral's Department, August 1994); Caroline Hoyle et al, "Evaluation of the "One Stop Shop" and Victim Statement Pilot Projects' (Report for the Home Office, Department of Law, University of Bristol, 1998); Sanders et al, above n 3; Rock, 'Hearing Victims of Crime', above n 95, 214-16, $221-2$. 
the 'Victim Impact Statement Information Package' advises victims that ' $[t]$ he court will only consider the victim impact statement in connection with the determination of the sentence to be imposed if it considers that it is appropriate to do so'. ${ }^{133}$ There is no explanation about what it means to 'consider' a VIS, when that might be 'appropriate', or what the outcomes of such consideration might be. No doubt this is in large part because it is hard to explain to a layperson the highly discretionary nature of sentencing, the multiple and conflicting considerations involved, the role of value judgments made in the process of instinctive synthesis, and the range of outcomes possible.

In NSW, many family victims receive advice from a range of victim support services. It would not be surprising if some of those services understand from the Attorney-General's statements that, as a result of the new law, VISs will have greater influence on penalties imposed and advise family victims accordingly. Given the findings of the case study however, such advice could inappropriately inflate victim expectations with regard to the impact of their VIS on penalty with negative consequences for both victims and confidence in criminal justice processes more generally.

The sentencing judge in Loveridge also alluded to another way in which VISs from family victims might count for something - that is, by providing family victims with a platform from which to have a say about the proper penalty to be imposed. As already noted however, the new law does not change the longstanding position at common law whereby the attitude of victims of crime to the penalty to be imposed is irrelevant. If the legislature intended to change this aspect of the law then it would have to do so in very clear language. ${ }^{34}$

Ultimately, if family victims expect that their VISs will influence the penalty in 'their' case in the sense that the penalty imposed will be more severe because of their suffering, then their expectations will most likely be disappointed. Not only might family victims be disappointed, angered or frustrated that their VIS did not achieve what is perceived as the 'proper' penalty, but they could also experience significant distress and feelings of guilt that their loved one was not valued more highly by the law and that their suffering is not sufficiently substantial when compared with the suffering of family victims in other cases. ${ }^{135}$ It is important not to underestimate the adverse consequences of such pressure and guilt for members of an already vulnerable group. ${ }^{136}$

The use of VISs in determining penalty under the new law is further complicated by the requirement of a prosecution application. Potential adverse

133 NSW Department of Justice (Victim Services), 'Victim Impact Statement: Information Package' (July 2017) $5<$ http://www.victimsservices.justice.nsw.gov.au/Documents/bk03_vis.pdf $>$.

134 This is the case in legislation in Northern Territory and South Australia. Section 106B(5A) of the Sentencing Act (NT) provides that a VIS 'may contain a statement as to the victim's wishes in respect of the order that the court may make in relation to the offence'.

135 Rock, 'Hearing Victims of Crime', above n 95, 211, 215, 219-23.

136 Judith Lewis Herman, 'The Mental Health of Crime Victims: Impact of Legal Intervention' (2003) 16 Journal of Traumatic Stress 159; Paul Rock, After Homicide: Practical and Political Responses To Bereavement (Clarendon Press, 1998); Kim ME Lens, Anthony Pemberton and Stefan Bogaerts, 'Heterogeneity in Victim Participation: A New Perspective on Delivering a Victim Impact Statement' (2013) 10 European Journal of Criminology 479. 
consequences for family victims are obvious if the prosecution elects not to apply to the sentencing court to have VISs taken into account in sentencing. Guidelines published by the NSW Office of the Director of Public Prosecutions ('DPP') inform victims of their three options with regard to VISs:

- do not provide a VIS;

- do provide a VIS but it is not taken into account; or

- do provide a VIS and the prosecution applies to the court to have the statement taken into account on sentence for the offence. ${ }^{137}$

Family victims are told that the second and third options are subject to prosecution approval of the contents of the statement and they are 'encouraged' to consult with prosecutors during this process. ${ }^{138}$ As to the third option, the guidelines do not explain the basis upon which the prosecution will select cases and the case study findings show that the prosecution does not make an application in every case. From a practical point of view, whether or not the prosecution makes an application, VISs can still be submitted to the court and the harm caused to the victims will be part of the objective seriousness of the offence. However, it is likely that because many family victims will not understand the operation of the law, they could interpret the prosecution's failure to make an application as a lack of respect to the deceased and the deceased's family. Again, the potential for adverse consequences for the victims and confidence in the administration of justice are obvious.

\section{B Expressive Function}

As already argued, the expressive functions of VISs were particularly important for many family victims under the former law. Through their VISs, victims were provided with opportunities to talk about their experiences, feelings, loss and the qualities of the deceased; in turn, sentencing judges could recognise and acknowledge victim suffering through their sentencing judgments. ${ }^{139}$ Ideally, the operation of the new law should not interfere with this valued expressive function.

At first glance, the contention that the new provisions do not change the practical operation of the law should also mean that the expressive function of VISs remains unchanged. And certainly this will generally be the case. However, it is arguable that if the prosecution applies to have the VISs taken into account as evidence of an aggravating factor in sentencing, then there is potential for constraints to be placed on the expressive function of VISs. As part of the prosecution case, it is likely that VISs will be proffered as evidence of substantial suffering caused to family victims. In order for a VIS to serve this legal function, the statement will need to be persuasive in an appropriately legal manner and, in

137 NSW Office of Director of Public Prosecutions, Victim Impact Statements (2013)<http://www.odpp. nsw.gov.au/victims-witnesses/victim-impact-statements>.

138 Ibid.

139 Booth, Accommodating Justice, above n 2, 63-94; Christine M Englebrecht, 'Where Do I Stand? An Exploration of the Rules That Regulate Victim Participation in the Criminal Justice System' (2012) 7 Victims and Offenders 161, 175-9; Rock, 'Hearing Victims of Crime', above n 95, 210-12, $219-24$. 
the realm of evidence, it is clear that legal goals can and frequently do conflict with victim interests. By virtue of the DPP guidelines relating to VISs generally, ${ }^{140}$ family victims are already subject to a fairly stringent editing process before their VIS can be submitted to the court and this is a major source of frustration for family victims. ${ }^{141}$ Crown lawyers are advised to ensure that drafts of VISs from family victims comply with legal requirements before the sentencing hearing. ${ }^{142}$ During this process, VISs can be changed or rejected. However, as a piece of prosecution 'evidence', further restrictions could be imposed on the content of VISs: the story victims are able to tell, the experiences and feelings recounted, and the manner in which the story is told. Drawing on research of victims' experiences in other jurisdictions, family victims could be pressured or coerced into crafting and delivering VISs that address certain matters (and exclude others) and/or express (or desist from expressing) particular emotions in order for that statement to be better aligned with the prosecution's goals. ${ }^{143}$ These restrictions are not to ensure that the content of the VIS meets legal requirements, but to shape the VIS narrative into persuasive 'legal evidence', to focus on those aspects that might carry more 'weight' in the process. It is very likely that such constraints on the expressive functions of their VISs could exacerbate frustration, anger and distress for family victims.

A final point to consider is the potential negative impact of the operation of the new law on victims' experiences in the courtroom. The Victim Impact Information Package warns victims that the defence is entitled to cross-examine them on the contents of their statements. ${ }^{144}$ Although section 28(4) facilitates such cross-examination, research suggests that it is very unlikely to occur and should not be a major concern for family victims. Victims are not warned however, that if VISs have the potential to increase penalty, then, following Tuala, there will be increased pressure on offenders to scrutinise VISs closely both before and during the hearing. Such scrutiny might lead to requests to edit statements before the hearing or take the form of challenges made to the content or weight of the statements during the hearing either by objection or submissions. The stakes will be high for homicide offenders if VISs can influence the penalty imposed and it is likely that this possibility, together with law as expounded in Tuala, will lead to increased scrutiny of VISs and more challenges to the statements in the courtroom. Not only could this generate instability and disruption in legal proceedings but the potential for negative impacts on many family victims is obvious.

140 NSW Office of the Director of Public Prosecutions, Prosecution Guidelines (at 1 June 2007) r 19.

141 Booth, Accommodating Justice, above n 2; Englebrecht, above n 139.

142 NSW Office of the Director of Public Prosecutions, Prosecution Guidelines (at 1 June 2007) r 19.

143 Edna Erez, Julie L Globokar and Peter R Ibarra, 'Outsiders Inside: Victim Management in an Era Of Participatory Reforms' (2014) 20 International Review of Victimology 169, 177-9; Amanda Konradi and Tina Burger, 'Having the Last Word: An Examination of Rape Survivors' Participation in Sentencing' (2000) 6 Violence Against Women 351, 380; Karen-Lee Miller, 'Purposing and Repurposing Harms: The Victim Impact Statement and Sexual Assault' (2013) 23 Qualitative Health Research 1445, 1450-1; Mary Lay Schuster and Amy Propen, 'Degrees of Emotion: Judicial Responses to Victim Impact Statements' (2010) 6 Law, Culture and the Humanities 75, 90-100.

144 NSW Department of Justice (Victim Services), above n 133. 


\section{CONCLUSION}

The new law emerged as a political response to the perceived leniency afforded to the offender for the manslaughter of Thomas Kelly in 2013. According to the then Attorney-General, a major problem in that case was that VISs from the family victims did not 'count for anything' in the sentencing process. If the Attorney-General meant that the VISs did not influence the penalty imposed, this claim was a correct statement of the law under Previtera. What the Attorney-General did not acknowledge however is that VISs were nonetheless relevant to sentencing homicide offenders; VISs were not ignored or unimportant in the process. From an instrumental perspective, they exemplified harm that is an inherent characteristic of homicide offending and relevant to assessment of the objective circumstances of the offence. Judges also used VISs in their sentencing judgments to recognise and acknowledge victims' experiences as well as exemplify publicly the devastating consequences of the offending for the victim's family and the wider community. From an expressive perspective, VISs provided family victims with an opportunity to be involved in the legal process, to speak about their experiences of victimisation and, perhaps most importantly, to render the deceased visible in the proceedings.

According to Parliament, the former approach to VISs in homicide matters constituted insufficient legal recognition of family victim suffering in sentencing. The second reading speech and explanatory memoranda indicate parliamentary intention to overrule Previtera and enable sentencing courts to use VISs to influence the penalty imposed in 'appropriate' cases. In this way, the role of VISs in sentencing homicide offenders would be enhanced and VISs would 'count for something' in the process.

It has been argued however, that the new law has not enhanced the role of VISs in sentencing homicide offenders, nor is it likely to change the manner in which VISs from family victims are used in sentencing in the vast majority of cases. The harm sustained by family victims continues to be relevant to the objective circumstances of the offending and homicide offences by their very nature are serious. Furthermore, given the very real risk of double-counting, it will only be in very rare cases that a VIS could be used as evidence of an aggravating factor so as to increase the penalty to be imposed on the offender. It is highly doubtful that the result in Loveridge (that is, as re-sentenced by the CCA) would have been different under the new law. Manslaughter offences are notoriously difficult to sentence given the wide-ranging circumstances of each case. As to the seriousness of the offence, while the outcomes - death and loss to family victims - are the same as murder, the culpability of the offender is lower and the penalty will not be as severe. Victim impact statements will not change this outcome.

Not only could victim expectations with regard to the impact of their VIS on penalty be frustrated but the operation of the new law has the potential for significant adverse impacts on their experiences in the courtroom including: pressure or coercion to submit a VIS in circumstances where they may not want to; further encroachment on their agency and autonomy in preparing and 
delivering their VIS, notably constraints on what can be expressed; feelings of distress, anger and guilt if it is perceived that their VISs fail to achieve the penalty desired; and overall decline in confidence in criminal justice processes.

Ultimately, the law is a blunt instrument in the context of punishment and sentencing: it cannot and should not be put forward as a method to assuage victim suffering in the aftermath of homicide. As McCallum $\mathrm{J}$ said in $R v$ Jenbare:

[the VISs] painted a picture of a warm and vivacious woman with a beautiful soul. I have had regard to that material in the manner allowed by law [citing Halloun and Sumpton]. I thank the authors of those statements for sharing their stories of [the deceased's] life. Her death has caused intense pain and grief ... On behalf of the Court, I pay my respect to the family and acknowledge their grief and sadness. It is recognised that the sentence to be imposed on the offender will not bring redress for their loss. That is not and could not appropriately be the object of sentencing by a court. The loss of a human life is tragic; the recognition of that fact is an important premise of the sentencing task. It will be understood, at the same time, that a just criminal justice system must have regard to all considerations that serve the established objects of the sentencing process. ${ }^{145}$

The limitations of the law for this purpose must be recognised and reflected in criminal justice policy. Rather than changing the language but not the operation of the law, family victims would be assisted by greater government investment in resources to support and assist victims of crime. 